\title{
FAKTOR-FAKTOR YANG MEMPENGARUHI RENDAHNYA KUNJUNGAN BALITA KE POSYANDU DI WILAYAH KERJA UPTD PUSKESMAS LAMURUKUNG
}

\author{
Hasliana \\ AKBID Bina Sehat Nusantara Bone \\ Alamat korespondensi : (ahasliana @gmail.com/0812426155532)
}

\begin{abstract}
ABSTRAK
Posyandu merupakan wadah untuk mendapatkan pelayanan dasar untuk masyarakat yang dilaksanakan oleh kader yang telah dilatih d ibidang kesehatan dan $\mathrm{KB}$, dimana anggotanya berasal dari PKK, tokoh masyarakat dan pemudi. Tujuan penelitian ini adalah untuk mengetahui faktor-faktor yang mempengaruh irendahnya kunjungan balita ke Posyandu di wilayah kerja UPTD Puskesmas Lamurukungkung. Penelitian ini dilakukan secara deskriptif dengan menggunakan data sekunder dari empat posyandu di wilayah kerja UPTD Puskesmas Lamurukung tahun 2017. untuk mengetahui rendahnya kunjungan balita ke posyandu dengan melihat variabel-variabel terkait, yaitu umur balita, pekerjaan ibu dan jarak tempat tinggal. Berdasarkan hasil analisis data diperoleh jumlah responden dengan kunjungan secara teratur sebanyak 65 responden atau sebesar $65.7 \%$,, kunjungan responden ke posyandu dengan variabel umur lebih banyak pada kategori baduta (12-23 bulan) yaitu sebesar $67.7 \%$. Variabel pekerjaan ibu jauh lebih banyak pada responden dengan status bekerja sebesar $91.9 \%$ dan pada variabel karakter tempat tinggal menuju posyandu lebih banyak pada kategori jarak jauhya itu sebesar $80.8 \%$. Faktor yang berpengaruh terhadap rendahnya kunjungan balita ke Posyandu di wilayah kerja UPTD Puskesmas Lamurukungkung adalah variabel jarak tempat tinggal.
\end{abstract}

Kata Kunci :Posyandu, umur, pekerjaan, jarak tempat tinggal.

\section{PENDAHULUAN}

World Health Organization (WHO, 2016) Kesehatan reproduksi, ibu, bayi baru lahir dan anak adalah salah satu dari empat kategori indeks cakupan Universal Health Coverage (UHC). Kategori ini mencakup empat indikator cakupan: keluarga berencana; perawatan antenatal (empat kunjungan atau lebih); cakupan imunisasi lengkap anak; dan perilaku pencarian kesehatan untuk radang paru-paru anak. Cakupan utama kesenjangan untuk keempat indikator ini bertahan di banyak negara, terutama di kalangan populasi yang kurang beruntung. Secara global pada tahun 2016, ada 155 juta anak di bawah usia lima tahun yang mengalami stunting (terlalu pendek untuk usia mereka), 52 juta terbuang (terlalu ringan untuk tinggi badan mereka) dan 41 juta kelebihan berat badan (terlalu berat untuk tinggi badan mereka) (World Health Organization, 2016).

Renstra Kementerian Kesehatan 20102014 dan Instruksi Presiden No. 3 tahun 2010 telah ditetapkan bahwa pada tahun 2014 sekurangnya $80 \%$ anak di timbang secara teratur di Posyandu. Pencapaian kegiatan pemantauan pertumbuhan pada tahun 2011 adalah $71,4 \%$ dan beberapa provinsi telah mencapai di atas 80\%. (Profil Kesehatan Indonesia, 2016).

Pencapaian posyandu purnama dan Persentase cakupan kunjungan bayi di Sulawesi Selatan tahun 2017 sebesar 88,08\%. Adapun Kabupaten/Kota yang memiliki cakupan kunjungan bayi minimal 4 kali tertinggi (memenuhi standar nasional $=90 \%$ ) yaitu Kab. Selayar, Bulukumba, Bantaeng, Takalar, Gowa, Sinjai, Pangkep, Barru, Soppeng, Wajo, Sidrap, Pinrang, Enrekang, Luwu, Tana Toraja, Luwu Utara, Luwu Timur, Toraja Utara, Makassar, Parepare dan Palopo sedangkan Kabupaten / Kota dengan cakupan kunjungan bayi terendah adalah Kabupaten Jeneponto, Maros, dan Bone. (Profil Kesehatan Sulawesi Selatan, 2016).

Di Kabupaten Bone tahun 2015 jumlah posyandu yang tercatat sebanyak 949 unit, dengan rasio posyandu per 100 balita sebesar 1,40 belum mencapai target RPJMD sebesar 1,78 dengan ratio posyandu per desa sekitar 2,50 . Adapun posyandu yang aktif sebanyak 927 unit atau $97,68 \%$. Situasi ini tetap perlu mendapat perhatian bila ingin meningkatkan kualitas posyandu menuju posyandu mandiri. (Profil Kesehatan Kabupaten Bone, 2015).

Jumlah balita di UPTD Puskesmas Lamurukung Tahun 2016 sebanyak 186 balita 
dan yang berkunjung ke posyandu sebanyak $121(65.05 \%)$ balita, sedangkan pada tahun 2017 terjadi penurunan kunjungan, yaitu jumlah balita sebanyak 170 dan yang berkunjung ke posyandu 99 (58.23) balita dengan rincian 1) Posyandu Bougenfile 42 balita, 2) Posyandu Kamboja 22 balita, 3) Posyandu Melati 19 balita dan 4) Posyandu Anggrek 16 balita, serta yang tidak berkunjung sebanyak 71 (41.76) (UPTD Puskesmas Lamurukung, 2016-2017).

Berdasarkan latar belakang tersebut diatas, penulis tertarik untuk mengetahui faktor yang melatar belakangi rendahnya kunjungan ke Posyandu untuk pemeriksaan kesehatan anak, sehingga peneliti ingin mengetahui "Faktor-faktor rendahnya kunjungan balita ke posyandu di wilayah kerja UPTD Puskesmas Lamurukung tahun 2017".

\section{BAHAN DAN METODE}

\section{Lokasi, Populasi Sampel}

Penelitian ini dilakukan di posyandu wilayah kerja UPTD Puskesmas Lamurukung bulan Juli tahun 2018. Populasi dalam penelitian ini yaitu 99 balita yang berkunjung ke posyandu di wilayah kerja UPTD Puskesmas Lamurukung tahun 2017. Sampel dalam penelitian ini yaitu sebanyak 99 orang.

\section{Pengumpulan Data}

Data penelitian yang digunakan adalah data sekunder yang diperoleh dengan cara mengumpulkan data yang telah memenuhi kriteria pengambilan sampel yang diambil dari dokumen rekam medik dan melakukan tabulasi untuk selanjutnya dilakukan analisa variabel penelitian.

\section{Pengolahan Data}

1. Editing Memeriksa data dan memperjelas serta melakukan pengecekan terhadap data yang telah dikumpulkan berdasarkan rekapan rekam medik.

2. Tabulating data yang telah diperoleh dilakukan penataan data kemudian disusun dalam bentuk tabel distribusi (Notoatmodjo, 2010).

3. Processing adalah tahapan kegiatan memproses agar dapat dianalisis.

4. Cleaning adalah tahapan kegiatan pengecekan data yang sudah dimasukkan dan melakukan koreksi jika ada kesalahan.

\section{Analisis Data}

1. Analisis Univariat

Dimaksudkan untuk menjelaskan atau mendeskrifsikan karakteristik setiap variabel penelitian.
2. Analisis Bivariat

Analisis bivariat yang dilakukan terhadap dua variabel yang diduga berhubungan atau berkolerasi.

\section{HASIL PENELITIAN}

1. Analisis univariat

Table 1 Jumlah kunjungan balita ke posyandu.

\begin{tabular}{|c|c|c|}
\hline Posyandu & $\mathrm{n}$ & $\%$ \\
\hline Bougenfile & 38 & 38.4 \\
\hline Kamboja & 17 & 17.2 \\
\hline Melati & 20 & 20.2 \\
\hline Anggrek & 24 & 24.2 \\
\hline Total & 99 & 100.0 \\
\hline
\end{tabular}

Tabel 1 menunjukan bahwa jumlah kunjungan balita di empat posyandu lebih tinggi pada posyandu Bougenfile sejumlah 38 atau sebesar $38.4 \%$ sedangkan kunjungan terendah pada posyandu Kamboja dengan jumlah 17 responden atau sebesar $17.2 \%$.

a. Karakteristik responden

Table 2 Karakteristik responden. $(\mathrm{n}=99)$

\begin{tabular}{|l|c|c|}
\hline Karakteristik & $\mathrm{n}$ & $\%$ \\
Responden & & \\
Umur ibu & & \\
$<20 \&>35$ thn & 26 & 26.3 \\
$20-35$ thn & 73 & 73.7 \\
\hline Pendidikan ibu & & \\
SD \& SMP & 64 & 64.6 \\
SMA \& PT & 35 & 35.4 \\
\hline
\end{tabular}

Gambaran

karakteristik responden 2 menunjukkan bahwa lebih banyak responden berumur antara 2035 tahun yaitu sebesar $73.7 \%$ dan responden lebih banyak berpendidikan SD dan SMP yaitu sebesar $64.6 \%$.

b. Analsis data variabel kunjungan

Tabel 3 Distribusi frekuensi responden berdasarkan kunjungan ke posyandu

\begin{tabular}{|l|c|c|}
\hline $\begin{array}{l}\text { Kunjungan } \\
\text { Posyandu }\end{array}$ & $\mathrm{n}$ & $\%$ \\
\hline Teratur & 66 & 66.7 \\
\hline Tidak Teratur & 33 & 33.3 \\
\hline Total & 99 & 100.0 \\
\hline
\end{tabular}

Hasil penelitian tabel 3 menunjukkan bahwa lebih banyak yang melakukan kunjungan ke posyandu secara teratur yaitu sebanyak 65 responden atau sebesar $65.7 \%$ dan secara tidak teratur sebesar $33.3 \%$. 
c. Analisis data variabel umur anak Tabel 4 Distribusi frekuensi responden berdasarkan umur anak $(n=99)$

\begin{tabular}{|l|c|c|c|}
\hline $\begin{array}{c}\text { Umur } \\
\text { Anak }\end{array}$ & Frekuensi & Persen & $\begin{array}{c}\text { Kumulatif } \\
\text { persen }\end{array}$ \\
\hline Balita & 67 & 67.7 & 67.7 \\
\hline Baduta & 32 & 32.3 & 100.0 \\
\hline Total & 99 & 100.0 & \\
\hline
\end{tabular}

Hasil penelitian tabel 4 menunjukkan bahwa lebih banyak pada umur balita yaitu sebanyak 67 responden atau sebesar $67.7 \%$ dan pada umur baduta sebesar $32.3 \%$.

d. Analisis data variabel pekerjaan ibu Tabel 5 Distribusi frekuensi responden berdasarkan pekerjaan ibu $(\mathrm{n}=99)$

\begin{tabular}{|c|c|c|}
\hline Pekerjaan Ibu & $\mathrm{n}$ & $\%$ \\
\hline Bekerja & 91 & 91.9 \\
\hline Tidak Bekerja & 8 & 8.1 \\
\hline Total & 99 & 100.0 \\
\hline
\end{tabular}

Hasil penelitian tabel 5 menunjukkan bahwa lebih banyak oleh ibu yang bekerja yaitu sebanyak 91 responden atau sebesar $91.9 \%$ dan oleh ibu yang tidak bekerja sebesar $8.1 \%$.

e. Analisis data variabel jarak tempat tinggal

Tabel 6 Distribusi frekuensi responden berdasarkan jarak tempat tinggal $(n=99)$

\begin{tabular}{|c|c|c|}
\hline $\begin{array}{c}\text { Jarak Tempat } \\
\text { Tinggal }\end{array}$ & Frekuensi & Persen \\
\hline Dekat & 80 & 80.8 \\
\hline Jauh & 19 & 19.2 \\
\hline Total & 99 & 100.0 \\
\hline
\end{tabular}

Hasil penelitian tabel 6 menunjukkan bahwa lebih banyak responden dengan jarak dekat yang melakukan kunjungan yaitu sebanyak 80 responden atau sebesar $80.8 \%$ dan dengan jarak jauh sebesar $19.2 \%$.

f. Analisa data variable umur anak Table 7 Pengaruh umur anak dengan kunjungan posyandu $(n=99)$

\begin{tabular}{|l|c|c|c|c|c|c|c|}
\hline \multicolumn{10}{|c|}{ Kunjungan } \\
\hline $\begin{array}{l}\text { Jarak } \\
\text { tempat } \\
\text { tinggal }\end{array}$ & \multicolumn{2}{|c|}{ Teratur } & $\begin{array}{c}\text { Tidak } \\
\text { teratur }\end{array}$ & \multicolumn{2}{|c|}{ Total } & $\mathrm{X}^{2}$ Hit \\
\cline { 2 - 8 } & $\mathrm{n}$ & $\%$ & $\mathrm{n}$ & $\%$ & $\mathrm{n}$ & $\%$ & \\
\hline Dekat & 60 & 90,9 & 20 & 60,6 & 80 & 80,8 & 20,15 \\
\hline Jauh & 6 & 9,1 & 13 & 39,4 & 19 & 19,1 & \\
\hline Jumlah & 66 & 100 & 33 & 100 & 99 & 100 & \\
\hline $\mathrm{X}^{2}$ tabel & \multicolumn{10}{|c|}{2,84} & \multicolumn{10}{|c|}{} \\
\hline
\end{tabular}

Tabel 7 menunjukkan bahwa lebih banyak responden umur balita yang berkunjung ke posyandu secara teratur yaitu sebesar $66.7 \%$ dibanding responden umur baduta sebesar $33.3 \%$ - Berdasarkan hasil uji Chi square $X^{2}$ Hit $<X^{2}$ tabel atau 1,92<2,84 berarti $\mathrm{Ha}$ ditolak dan Ho diterima sehingga dapat disimpulkan bahwa tidak ada pengaruh antara umur anak dengan kunjungan balita ke posyandu.

g. Analisa data variable pekerjaan ibu Table 8 Pengaruh pekerjaan ibu dengan kunjungan

\begin{tabular}{|c|c|c|c|c|c|c|c|}
\hline \multicolumn{8}{|c|}{ Kunjungan } \\
\hline \multirow{2}{*}{$\begin{array}{c}\text { Pekerjaan } \\
\text { ibu }\end{array}$} & \multicolumn{2}{|c|}{ Teratur } & \multicolumn{2}{|c|}{$\begin{array}{l}\text { Tidak } \\
\text { teratur }\end{array}$} & \multicolumn{2}{|c|}{ Total } & $\begin{array}{l}X^{2} \\
\text { Hit }\end{array}$ \\
\hline & $\mathrm{N}$ & $F$ & $\mathrm{~N}$ & $\mathrm{~F}$ & $\mathrm{~N}$ & $\mathrm{~F}$ & \multirow{4}{*}{1,92} \\
\hline Bekerja & 62 & 93,9 & 29 & 69,7 & 91 & 91,9 & \\
\hline $\begin{array}{c}\text { Tidak } \\
\text { bekerja }\end{array}$ & 4 & 6,1 & 4 & 30,3 & 8 & 8,0 & \\
\hline Jumlah & 66 & 100 & 33 & 100 & 99 & 100 & \\
\hline $\mathrm{X}^{2}$ tabel & \multicolumn{7}{|c|}{2,84} \\
\hline
\end{tabular}

Tabel 8 menunjukkan bahwa lebih banyak respoden dengan status bekerja dan secara teratur berkunjung ke posyandu yaitu sebanyak $93.9 \%$ dibanding responden status tidak bekerja sebesar $6.1 \%$.Berdasarkan hasil uji Chi square $X^{2} H i t<X^{2}$ tabel atau 1,92<2,84 berarti Ha ditolak dan Ho diterima sehingga dapat disimpulkan bahwa tidak ada pengaruh antara pekerjaan ibu dengan kunjungan balita ke posyandu.

h. Analisa data variable jarak tempat tinggal

Table 4.10 Pengaruh jarak tempat tinggal dengan kunjungan

\begin{tabular}{|c|c|c|c|c|c|c|c|}
\hline \multicolumn{8}{|c|}{ Kunjungan } \\
\hline \multirow{2}{*}{$\begin{array}{l}\text { Jarak } \\
\text { tempat } \\
\text { tinggal }\end{array}$} & \multicolumn{2}{|c|}{ Teratur } & \multicolumn{2}{|c|}{$\begin{array}{c}\text { Tidak } \\
\text { teratur }\end{array}$} & \multicolumn{2}{|c|}{ Total } & $X^{2}$ Hit \\
\hline & $\mathrm{N}$ & $\mathrm{F}$ & $\mathrm{N}$ & $\mathrm{F}$ & $\mathrm{N}$ & $\mathrm{F}$ & \multirow{4}{*}{$-20,15$} \\
\hline Dekat & 60 & 90,9 & 20 & 60,6 & 80 & 80,8 & \\
\hline Jauh & 6 & 9,1 & 13 & 39,4 & 19 & 19,1 & \\
\hline Jumlah & 66 & 100 & 33 & 100 & 99 & 100 & \\
\hline $\mathrm{X}^{2}$ tabel & \multicolumn{7}{|c|}{2,84} \\
\hline
\end{tabular}

square $X^{2} H i t>\quad X^{2}$ tabel atau $20,15>2,84$ berarti Ha diterima dan $\mathrm{Ho}$ ditolak sehingga dapat disimpulkan bahwa ada pengaruh antara pekerjaan ibu dengan kunjungan balita ke posyandu. 


\section{PEMBAHASAN}

1. Pengaruh umur anak dengan kunjungan posyandu

Umur atau usia adalah satuan waktu yang mengukur waktu keberadaan suatu benda atau makhluk, baik yang hidup maupun yang mati. Dalam kamus besar bahasa Indonesia dijelaskan bahwa umur adalah lama waktu hidup atau ada (sejak dilahirkan atau diadakan). umur 12 hingga 35 bulan merupakan umur yang paling berpengaruh terhadap kunjungan karena pada umur ini merupakan pertumbuhan dasar yang akan mempengaruhi dan menentukan perkembangan anak selanjutnya (Tranmianingsih \& Tantoro, 2012).

Dari seluruh responden yang diteliti, anak kelompok umur balita yang berkunjung ke Posyandu tahun 2017 yaitu sebesar $67,7 \%$ jauh lebih besar dibanding responden dengan umur baduta yang berkunjung ke Posyandu yaitu $32,3 \%$. Hal ini dikarenakan umur yang $\geq 12$ bulan dan mendapatkan imunisasi lengkap dianggap sudah cukup melakukan kunjungan setiap bulan atau minimal 4 kali dalam 6 bulan.

Berdasarkan hasil analisis bivariat didapatkan hasil uji Chi square $\mathrm{X}^{2} \mathrm{Hit}<$ $X^{2}$ tabel atau 1,92<2,84 berarti Ha ditolak dan Ho diterima sehingga dapat disimpulkan bahwa tidak ada pengaruh antara umur anak dengan kunjungan balita ke posyandu

Hasil penelitian yang berbeda dilakukan oleh Reihana (2012), hasil analisis bivariat diperoleh ada hubungan yang signifikan antara ibu dengan kelompok usia bayi dengan ibu kelompok balita non bayi terhadap partisipasi ibu menimbang balitanya ke Posyandu dengan OR 2,0 yang berarti ibu anak balita kelompok bayi mempunyai peluang 2,0 kali lebih aktif partisipasinya menimbang balitanya ke Posyandu di banding dengan ibu anak usia balita non bayi. Hasil penelitian ini juga berbeda dengan penelitian yang dilakukan oleh Saputri (2010). Ada hubungan yang bermakna antara umur balita dengan kunjungan ke Posyandu di Kabupaten Pringsewu. Ada kecendrungan makin tinggi umur anak, makin rendah cakupan penimbangan rutin ( $<4$ Kali), sebaiknya semakin rendah umur anak semakin tinggi pula persentase anak

yang tidak pernah di timbang (Depkes, 2007 dalam dalam Reihana, 2012)

Faktor umur memiliki peran penting
dalam penentuan status gizi anak.
Kesalahan penentuan umur akan menyebabkan interprestasi status gizi menjadi salah. Menurut Puslibang Gizi Bogor (1980), batasan umur digunakan adalah tahun penuh (completed year) dan untuk anak umur 0-2 tahun digunakan bulan usia penuh (completed month) (Supariasa, 2002 dalam Reihana, 2012).

Faktor usia merupakan faktor yang mempengaruhi sikap seseorang terhadap kegiatan-kegiatan kemasyarakatan yang ada. Mereka dari kelompok usia menengah ke atas dengan keterikatan moral kepada nilai dan norma masyarakat yang lebih mantap, cenderung lebih banyak yang berpartisipasi dari pada mereka yang dari kelompok usia lainnya (Tranmianingsih \& Tantoro, 2012).

Sesuai dengan pendapat Sri poedji (2010) menyatakan bahwa umur hingga 35 bulan merupakan umur yang paling berpengaruh terhadap kunjungan karena pada umur ini merupakan pertumbuhan dasar yang akan mempengaruhi dan menentukan perkembangan anak selanjutnya. Khususnya balita diatas usia 36 bulan, karena ibu balita merasa bahwa anaknya sudah mendapatkan imunisasi lengkap dan perkembangan sosial anak semakin bertambah.

2. Pengaruh Pekerjaan ibu dengan kunjungan posyandu

Berdasarkan hasil analisis bivariat didapatkan hasil uji Chi square $X^{2} H i t<$ $X^{2}$ tabel atau $1,92<2,84$ berarti Ha ditolak dan Ho diterima sehingga dapat disimpulkan bahwa tidak ada pengaruh antara pekerjaan ibu dengan kunjungan balita ke posyandu.

Analisis ini menunjukan bahwa pekerjaan ibu tidak menjadi faktor yang mempengaruhi kunjungan balita ke posyandu. Notoatmodjo (2003) berpendapat bahwa individu yang berbeda pekerjaan mempunyai kecenderungan yang berbeda pula dalam menggunakan pelayanan kesehatan. Peneliti mengasumsikan bahwa mePengaruh Jarak tempat tinggal

Hasil penelitian ini sejalan dengan teori di atas, jarak kategori dekat dengan partisipasi membawa balitanya ke Posyandu $80.8 \%$ jauh lebih tinggi dibanding dengan responden yang jarak rumahnya jauh dan aktif membawa balitanya ke Posyandu yaitu sebesar $19.2 \%$. Berdasarkan hasil analisis bivariat didapatkan hasil uji Chi square $\mathrm{X}^{2} \mathrm{Hit>}$ $X^{2}$ tabel atau 20,15>2,84 berarti Ha diterima dan Ho ditolak sehingga dapat disimpulkan 
bahwa ada pengaruh antara pekerjaan ibu dengan kunjungan balita ke posyandu.

Sejalan dengan hasil penelitian yang dilakukan Idaningsih (2016) bahwa lbu balita dengan akses pelayanan kesehatan yang dekat dan kunjungan balitanya teratur sebesar 48 (76.2\%), sedangkan lbu balita dengan akses pelayanan kesehatan yang jauh dan kunjungan balitanya teratur sebesar $24(51.1 \%)$. Hasil uji statitik $p$ value $=0.011<0,05$ yang berarti ada kunjungan balita ke Posyandu, yang berarti Ibu balita dengan akses pelayanan kesehatan yang dekat akan melakukan kunjungan balita ke Posyandu lebih sering dibandingkan dengan lbu balita yang akses pelayanan kesehatannya jauh.

Peneliti berasumsi bahwa kondisi demografi daerah sangat mempengaruhi pola piker masyarakat untuk bersikap dengan membawa balita ke posyandu atau tidak, meskipun kategori jauh ( $>50 \mathrm{~m}$ ) jarak posyandu dengan tempat tinggal, namun masih dapat dijangkau oleh masyarakat dengan kendaraan roda dua. Mengingat kondisi masyarakat sekarang yang hampir setiap keluarga memiliki kendaraan motor roda dua.

\section{KESIMPULAN}

1. Tidak ada pengaruh antara umur anak dengan kunjungan balita ke posyandu.
2. Tidak ada pengaruh antara pekerjaan ibu dengan kunjungan balita ke posyandu.

3. Ada pengaruh antara pekerjaan ibu dengan kunjungan balita ke posyandu

\section{SARAN}

1. Bagi Tenaga Kesehatan/Puskesmas sebaiknya meningkatkan upaya sebagai fasilitator dalam menggalang kerjasama lintas sektoral melibatkan masyarakat, pemerintah dan swasta. untuk lebih giat mendorong masyarakat untuk memanfaatkan pelayanan kasehatan.

2. Bagi Instansi Pendidikan, diharapkan dapat meningkatkan kualitas pendidikan bagi para mahasiswa dengan penyediaan sarana dan prasarana yang mendukung peningkatan kemampuan mahasiswa sehingga dapat menghasilkan bidan yang professional.

3. Bagi masyarakat, diharapkan masyarakat khusunya ibu perlu meningkatkan dan mengembangkan pengetahuan pentingya kunjungan balita ke posyandu

4. Bagi peneliti selanjutnya, diharapkan dapat meneliti lebih dalam lagi serta menggunakan analisis yang berbeda sehingga memperkaya data penelitian serta dapat menjadi bahan dasar penelitian selanjutnya.

\section{DAFTAR PUSTAKA}

Ayu Idaningsih. 2016. Faktor-Faktor Yang Berhubungan Dengan Kunjungan Balita Ke Posyandu. Syntax Literate. Vol. 1, No. 2 Oktober $2016: 16-29$

Dinas Kesehatan Kabupaten Bone. 2014. Profil Kesehatan Kabupate Bone Tahun 2014. Kabupaten Bone.

Dinas Kesehatan Propinsi Sulawesi Selatan. 2016. Profil Kesehatan Propinsi Sulawesi Selatan Tahun 2016. Sulawesi Selatan.

Kementerian Kesehatan Republik Indonesia. 2016. Profil Kesehatan Indonesia Tahun 2016. Katalog Dalam Terbitan. Kementerian Kesehatan RI. Jakarta.

Reihana, 2012. Faktor Faktor Yang Berhubungan Dengan Partisipasi lbu Untuk Menimbang Balita ke Posyandu. Jurnal Kedokteran Yarsi 20 (3) : 143-157

Tranmianingsih. L \& Tantoro, S. 2012. Faktor Penyebab Ketidakhadiran Ibu yang Memiliki Balita ke Posyandu di Desa Banjar Seminai Kecamatan Dayun Kabupaten Siak.

World Health Organization, 2016. Monitoring Health Fot The SDGs, Sustainable Development Goals 